\title{
Physical and Mechanical Properties of Antimicrobial Film Form Lemongrass Oil Incorporated with Chitosan/Ascorbic Acid
}

\author{
Cuk Imawan ${ }^{1 *}$, Retno Yunilawati ${ }^{1}$, Vivi Fauzia ${ }^{1}$, Dwinna Rahmi ${ }^{2}$, Aminah Umar $^{3}$ \\ ${ }^{I}$ Departemen Fisika, Fakultas Matematika dan Ilmu Pengetahuan Alam, Universitas Indonesia, Kampus Depok, In- \\ donesia 16424 \\ ${ }^{2}$ Balai Besar Kimia dan Kemasan, Kementerian Perindustrian \\ ${ }^{3}$ Departemen Kimia, Fakultas Matematika dan Ilmu Pengetahuan Alam, Universitas Indonesia, Kampus Depok, In- \\ donesia 16424 \\ "Corresponding author.Email:_uk.imawan@sci.ui.ac.id
}

\begin{abstract}
Studies on the physical and mechanical properties of antimicrobial film from lemongrass oil incorporated with chitosan/ascorbic acid have been done to obtain an alternative biodegradable antimicrobial packaging. The objective of this research is to investigate changes in physical and mechanical properties of lemongrass oil/chitosan/ascorbic acid compared with chitosan/ascorbic acid. The concentration of lemongrass oil in chitosan/ascorbic film was $10 \%$. Moisture content, water solubility, and opacity were used to evaluate physical properties. The interaction between chitosan and lemongrass oil was evaluated using Fourier Transform-Infra Red (FTIR). While water barrier properties were investigated by water vapor transmission rate (WVTR), and mechanical properties were evaluated by tensile strength (TS) and elongation (E). Incorporating lemongrass oil in chitosan/ascorbic acid decreased moisture content $(15,81 \%$ to $12,62 \%$.) and water solubility $(24,58 \%$ to $20,41 \%)$ but increased the opacity. The FTIR spectra showed that there is a change in intensity in some bands due to the addition of lemongrass oil. Incorporation of lemongrass oil in chitosan/ascorbic acid film showed good barrier properties, decreased the tensile strength $\left(299 \mathrm{kgf} / \mathrm{cm}^{2}\right.$ to $\left.151 \mathrm{kgf} / \mathrm{cm}^{2}\right)$ but increased in elongation $(1,39 \%$ to $2,13 \%)$. The antimicrobial film from lemongrass oil incorporated with chitosan/ascorbic acid showed potential to be used as packaging in food.
\end{abstract}

\section{Keywords: Chitosan, Ascorbic, Antimicrobial, Film}

\section{INTRODUCTION}

The antimicrobial film is one part of active packaging consists of an antimicrobial agent and a matrix. The antimicrobial film of matrix could be natural or synthetic. Chitosan is an attractive polymer to be applied as a matrix because it is natural, renewable, biodegradable, and biocompatible [1]. Chitosan can be applied as an active packaging because it has film-forming properties in preparing films with good mechanical natures, selective permeability and naturally antimicrobial [2]. Film chitosan incorporated with natural ingredient extracts have shown significant improvement in bioactivities as declared by some research [3]. However, the addition of plant extracts antimicrobials can affect the physical and mechanical properties of chitosan, either improving it or giving a negative impact on its mechanical properties [4].

Lemongrass oil is an essential oil produced from the extraction of the Cymbopogon citratus. Lemongrass oil contains several chemical compounds consisting of neral, geranial, geraniol, geranyl acetate, beta-caryophyllene, and gamma cadinene [5] [6]. Citral has many roles in the bioactivity of lemongrass oil such as antibacterial [7] [8] [9] [10] [11] and antifungal [7]. Citral has antibacterial activity against bacteria, both in the oil form and in the vapour form [12] [5]. The use of lemongrass oil as an antimicrobial agent for antimicrobial packaging has been carried out in previous experiments using chitosan as a matrix. Lemongrass oil incorporated in chitosan/ascorbic acid at a concentration of $10 \%$ showed an antimicrobial activity on gram-negative bacteria E. Coli 
and gram-positive bacteria S. aureus [5]. This corporation has the potential to be applied as antimicrobial packaging, but the physical and mechanical properties have not been characterized. The physical and mechanical properties are important in the film that will be applied to packaging because they will affect the packaged product.

The aims of this research to investigate changes in physical and mechanical properties of lemongrass/chitosan/ascorbic acid film compared with chitosan/ascorbic acid in order to evaluate its use as antimicrobial packaging.

\section{METHODS}

\subsection{Materials}

Chitosan in powder form with a deacetylation degree of $90 \%$ was obtained from Bio Chitosan Indonesia. The chemical materials were ascorbic acid from Merck, glycerol was obtained from PT Wilmar Nabati Indonesia, and tween 80. Lemongrass oil as antimicrobial agent was obtained from Nusaroma.

\subsection{Methods}

\subsubsection{Preparation of the films.}

The antimicrobial film preparation was done by a solvent casting method. The $2 \mathrm{~g}$ of chitosan powder was dissolved in $100 \mathrm{~mL}$ of ascorbic acid solution $1 \% \mathrm{v} / \mathrm{v}$ ) and stirred with a magnetic stirrer for 2 hours at $50{ }^{\circ} \mathrm{C}$ to prepare chitosan solution. After chitosan was dissolved perfectly, $0,3 \mathrm{ml}$ of glycerol as plasticizers was added and stirred for 10 minutes. Tween 80 as an emulsifier was added of $0,2 \%(\mathrm{v} / \mathrm{v})$ and $10 \%(\mathrm{v} / \mathrm{v})$ of lemongrass oil as an antimicrobial agent were added and stirred for 5 minutes. This solution with the volume of $35 \mathrm{~mL}$ was poured on to flexi glass $15 \mathrm{~cm} \mathrm{x} 15 \mathrm{~cm}$ and left at room temperature for 2 days to form the film. The concentration of lemongrass oil was chosen based on previous study[5].

\subsubsection{Moisture content.}

The films moisture content was determined gravimetrically, by calculating the difference in the weight of the film before and after drying in an oven $110^{\circ} \mathrm{C}$.

\subsubsection{Water solubility.}

The films were cut into pieces $\left(1 \times 3 \mathrm{~cm}^{2}\right)$, weighed to an accuracy of $0.0001 \mathrm{~g}$ and placed in an oven at 110 ${ }^{\circ} \mathrm{C}$ until obtained a constant weight. The films then were soaked in $50 \mathrm{ml}$ of distilled water at $25{ }^{\circ} \mathrm{C}$ for $6 \mathrm{~h}$. The films after immersion were drying in an oven at $110{ }^{\circ} \mathrm{C}$ to reach a constant final weight. The water solubility $(\%)$ was calculated by the following formula:
Water solubility $(\%)=$

$\frac{\text { initial dry weight-final dry weight }}{\text { initial dry weight }} \times 100$

\subsubsection{Opacity.}

The films opacity was determined using a UV-Vis spectrophotometer (Shimadzu UV-2450) by measuring its absorbance at a wavelength of $600 \mathrm{~nm}$ and calculated as follow:

The opacity $=\frac{\text { Abs } 600}{\text { film thickness }(\mathrm{mm})}$

\subsubsection{Water vapour transmission rate (WVTR).}

The films WVTR were determine according to ASTM E96M-16 [6].

\subsubsection{Fourier Transform-Infra Red (FTIR) Anal- ysis.}

A Fourier Transform Infrared (FTIR) spectras were collected for the films using Thermo Nicolet iS5.

\subsubsection{Mechanical properties.}

The tensile strength (TS) and elongation at break (EB) were measured using a Universal Testing Yasuda Seiki Auto Strain Machine according to ASTM D882-18 [7]. Polycrystalline electron-doped $\mathrm{Eu}_{2-x} \mathrm{Ce}_{x} \mathrm{CuO}_{4+\alpha-\delta}$ with $x=0.09$ and 0.10 were synthesized by the solid-state reaction method. The precursors $\mathrm{Eu}_{2} \mathrm{O}_{3}, \mathrm{CuO}$, and $\mathrm{CeO}_{2}$ were grinded finely and pre-fired in air at $900{ }^{\circ} \mathrm{C}$ for 20 hours. Re-ground and pressed it into pellets with a diameter of $10 \mathrm{~mm}$. All samples were sintered at $1000{ }^{\circ} \mathrm{C}$ for 20 hours in air and preferred as as-grown sample with $(|\alpha| \ll 1)$. The as-grown samples were re-grounded, and then annealed at $900{ }^{\circ} \mathrm{C}$ for 10 hours in high purity $\mathrm{Ar}$ gas flowing. The annealing process was done to reduce the oxygen content at the so-called apical oxygen. The $\delta$ value was estimated by calculating the change of the sample weight before and after annealing indicating the value of reduction of oxygen in the sample. The X-Ray Diffraction (XRD) with $\mathrm{Cu}-K \alpha$ radiation was carried out to investigate the impurity phase and characteristics related to the sample structure such as the shape of the crystal structure, lattice parameters, $\mathrm{Cu}-\mathrm{O}$ bond lengths, and crystallite size of samples

\section{RESULTS AND DISCUSSION}

The physical properties of the films are summarized in Table 1. The incorporation the lemongrass oil in chitosan/ascorbic acid affected physical properties of the film. The incorporation of lemongrass oil to chitosan/ascorbic acid film decreased the moisture content 
from $15,81 \%$ to $12,62 \%$. Several researches on the essential oils incorporation in chitosan showed that the essential oils incorporation could decrease the moisture content in the chitosan film [8] [9] [10] [11]. The changes in moisture content are related to the hydrophilicity of chitosan. Chitosan has high hydrophilic properties so that it can absorb large amounts of water [4]. The lemongrass oil was hydrophobic so that its addition in chitosan reduces the water absorption ability of the chitosan/ascorbic acid film. The hydrophilicity of the film reduces, and the amount of absorbed water decreases.

Table 1. Physical properties of the films.

\begin{tabular}{|l|lr|l|l|}
\hline Films & $\begin{array}{l}\text { Moisture } \\
\text { content (\%) }\end{array}$ & $\begin{array}{l}\text { Water solu- } \\
\text { bility (\%) }\end{array}$ & $\begin{array}{l}\text { Opac- } \\
\text { ity }\end{array}$ \\
\hline $\begin{array}{l}\text { Chi- } \\
\text { tosan/ascorbic } \\
\text { acid }\end{array}$ & $\begin{array}{l}15,81 \quad \pm \\
0,58\end{array}$ & $\begin{array}{l}24,58 \\
0,21\end{array}$ & $\begin{array}{l}1,38 \pm \\
0,03\end{array}$ \\
\hline $\begin{array}{l}\text { Lemongrass/c } \\
\text { hitosan/ascor- } \\
\text { bic acid }\end{array}$ & $12,62 \pm$ & 0,44 & $20,41 \quad \pm$ & $2,68 \pm$ \\
& & 0,82 & 0,02 \\
\hline
\end{tabular}

One of the important characteristics for biodegradable films is water solubility because the water solubility affects the resistance of film to water. The addition of lemongrass oil to chitosan/ascorbic acid film decreased the water solubility from $24,58 \%$ to $20,41 \%$. The hydrophobic nature of lemongrass oil causes the decrease in the solubility of the film in water. The reduced number of $\mathrm{OH}$ bonds in chitosan and the presence of aliphatic groups from lemongrass oil to the chitosan film caused the solubility of the chitosan film in water was decreased [10]. The film opacity expresses its transparency which is an important character in its role as packaging. The film with high transparency is preferred because it confirms that the appearance and condition of the food are clearly visible during storage [10]. In this experiment, the opacity of the chitosan/ascorbic acid film increased from 1,38 to 2,68 with the addition of lemongrass oil, indicating the films became less transparent. Although opaque film is not preferred, the opaque film be considered as important for foods that are easily damaged by exposure to light [10].

The barrier properties are important characteristics of films for food packaging because they play a role in ensuring the quality of packaged products and can be used to predict shelf life. The barrier properties of a polymeric film are crucial for estimating or predicting the product shelf life [2]. Water vapor transmission rate (WVTR) is a parameter which describe the ability of a package to withstand the entry and exit of moisture from and into a packaged product. The WVTR value can be used to estimate the shelf life of packaged products. The
WVTR value of materials for food packaging should be as low as possible.

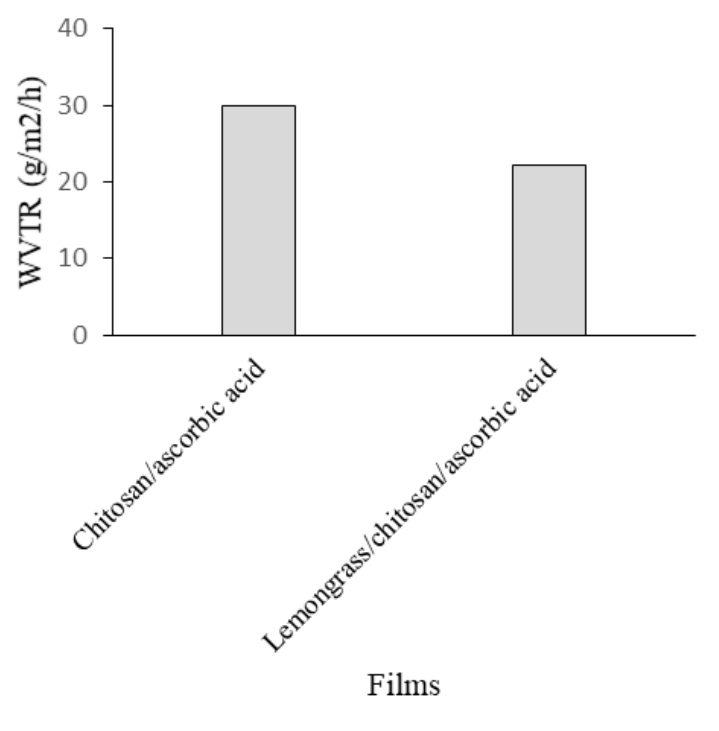

Figure 1. WVTR value of the films.

Figure 1 shows the value of chitosan/ascorbic acid film WVTR with the addition of $10 \%$ lemongrass oil. The chitosan/ascorbic acid film without lemongrass oil has a WVTR value of $30,04 \mathrm{~g} / \mathrm{m}^{2} / \mathrm{h}$. The addition of lemongrass oil decreased the WVTR value to 22,17 $\mathrm{g} / \mathrm{m}^{2} / \mathrm{h}$. Essential oils have hydrophobic properties were known to affect the barrier properties of polymer-based films. Incorporation of hydrophobic compound such as essential oils in edible film usually reduce the value of WVTR [10][12][8]. The lower WVTR of the lemongrass/chitosan/ascorbic acid film was caused by the interaction between the polysaccharide of chitosan and the polyphenolic compounds of lemongrass oil through hydrogen bond interactions [10]. This statement was supported by the FTIR spectra which shows the interaction of hydroxyl and amide groups of chitosan with lemongrass oil.

The XRD measurement of ECCO samples with $x=$ 0.09 (a) and 0.10 (b) shown in figure 1.

From the XRD measurement, it was found that the crystal structures of ECCO for sample with $x=0.09$ (a) and 0.10 (b) are all in tetragonal $T$ '-type and corresponds to the space group I4/mmm (ICSD: 98-007-2249). The lattice parameters of the ECCO can be calculated from the XRD peak pattern using equation (1).

$$
\frac{1}{d^{2}}=\frac{h^{2}+k^{2}}{a^{2}}+\frac{l^{2}}{c^{2}}
$$




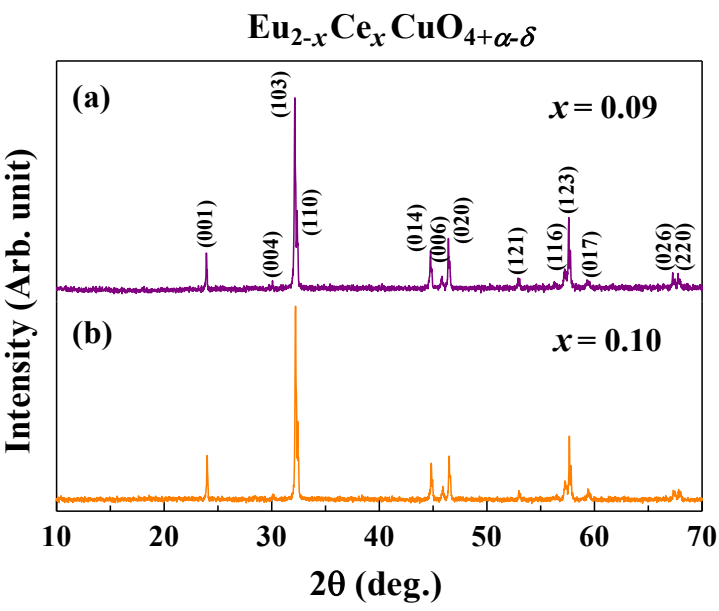

Figure 2. XRD patterns of $\mathrm{Eu}_{2-x} \mathrm{Ce}_{x} \mathrm{CuO}_{4+\alpha-\delta}$ samples with $x=0.09$ (a) and 0.10 (b).

Table 1. The effect of different concentrations at $\mathrm{Ce}(x)$ on the lattice parameters of $\mathrm{Eu}_{2-x} \mathrm{Ce}_{x} \mathrm{CuO}_{4+\alpha-\delta}$.

\begin{tabular}{|c|c|c|c|c|c|}
\hline $\mathrm{Ce}(x)$ & $\delta$ & $a(\AA)$ & $c(\AA)$ & $V\left(\AA^{3}\right)$ & GOF \\
\hline 0.09 & 0.037 & 3.9050 & 11.868 & 180.982 & 1.276 \\
\hline 0.10 & 0.047 & 3.9056 & 1.8656 & 180.996 & 1.103 \\
\hline
\end{tabular}
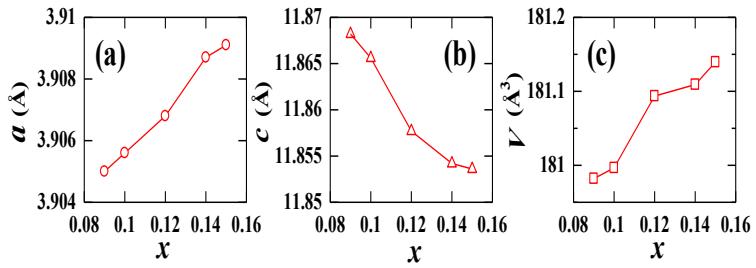

Figure 3. (a) The effect of Ce doping on the $a$-axis value (b) The effect of Ce doping on the $c$-axis value (c) The effect of Ce doping on the volume unit cell in the crystal structure of $\mathrm{Eu}_{2-x} \mathrm{Ce}_{x} \mathrm{CuO}_{4+\alpha-\delta}$. For comparison, lattice parameters data are added for $x=0.12$ [4], 0.14 [7], and 0.15 [8].

The Lattice parameters and the $\delta$ value of samples after annealing process are shown in table 1 . In previous studies, superconductivity appeared in ECCO sample at $x=0.15$ with $\delta$ value in the range between 0.0278 and 0.0950 [6].

Figure 2 shows the lattice parameter and volume of samples with Ce concentration value of $x=0.12$ which has value of $a$-axis $=3.9068 \AA, c$-axis $=11.8577 \AA$, and $V=181.0936 \AA^{3}$ [4]. With $x=0.14$ which has value of $a$ axis $=3.9087 \AA, c$-axis $=11.8542 \AA$, and $V=181.1091$ $\AA^{3}$ [7]. And With $x=0.15$ which has value of $a$-axis $=$
$3.90914 \AA, c$-axis $=11.85363 \AA$, and $V=181.1395 \AA^{3}$ [8].

From Figure 3, it is found that the lattice parameter $a$-axis increases by increasing the Ce concentration, while the lattice parameter $c$-axis decreases by increasing the Ce concentration. The volume of the unit cell of ECCO increases with the addition of $\mathrm{Ce}$, which means that there is a lattice expansion in the horizontal direction so that the conduction layer $\left(\mathrm{CuO}_{2}\right)$ and the charge reservoir widens. This tendency caused by $\mathrm{Ce}^{4+}$ ion $\left(r_{C e^{4+}}=1.03 \AA\right)$ is larger than $\mathrm{Eu}^{3+}$ ion $\left(r_{E u}{ }^{3+}=0.94 \AA\right)$ [1]. Decreasing the lattice parameter $c$-axis shorten the distance between the conduction layer and the charge reservoir thereby increases the superconductivity. Furthermore, the $\mathrm{Cu}-\mathrm{O}$ bond length also increases by increasing the lattice parameter $a$-axis with the addition of Ce concentration.
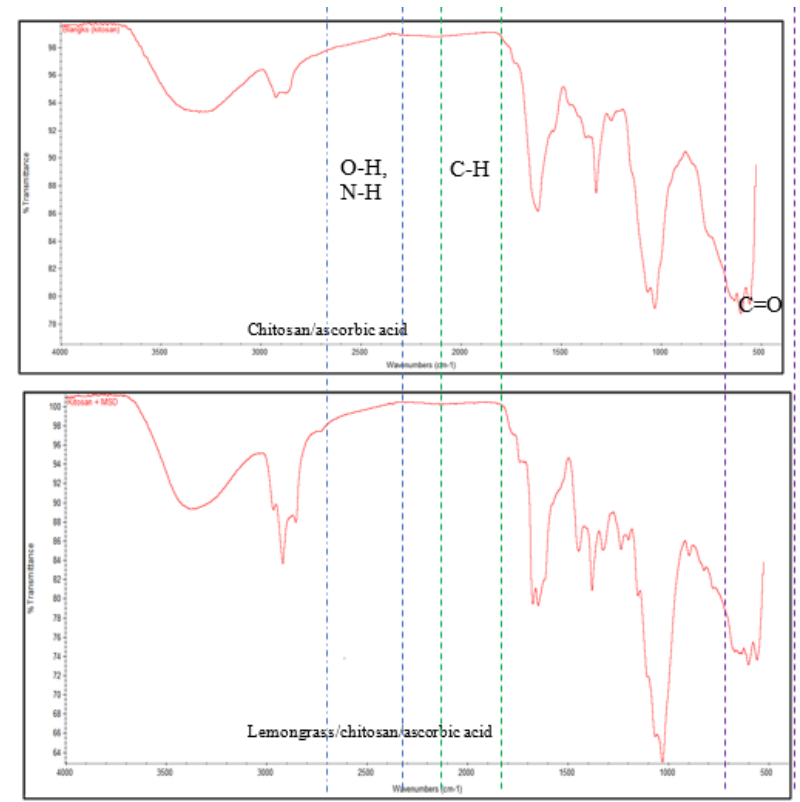

Figure 4. FTIR spectra of chitosan films.

The FTIR spectra of the film were observed to study the interaction of lemongrass oil with the chitosan functional group, as presented in Figure 4. The absorption band along $3500-3500 \mathrm{~cm}^{-1}$ indicates stretching vibrations of $-\mathrm{OH}$ and $-\mathrm{NH}$. In this wave number range, the band strength of chitosan/ascorbic acid film was higher than the lemongrass/chitosan/ascorbic acid film due to the lemongrass oil functional group interaction with functional group of $-\mathrm{NH}_{2}$ and $-\mathrm{OH}$ on chitosan molecules thus reduces the $\mathrm{N}-\mathrm{H}$ and $\mathrm{O}-\mathrm{H}$ stretching.

The absorption band at wavelength of $1700 \mathrm{~cm}^{-1}$ shows the presence of amide-I vibrations of the $\mathrm{C}=\mathrm{O}$ stretching [13]. The peak at $2928 \mathrm{~cm}^{-1}$ was due to $\mathrm{C}-\mathrm{H}$ stretching. 
At this wave number, there is a sharp increase in the intensity of the $\mathrm{C}-\mathrm{H}$ stretching and bending vibration, which is contributed by the aliphatic $\mathrm{C}-\mathrm{H}$ bonds present in lemongrass oil. The sharp absorption peak at 1700 $\mathrm{cm}^{-1}$ was higher with addition of lemongrass oil. This peak is the characteristic peak of the lemongrass oil and is associated with the $\mathrm{C}=\mathrm{O}$ stretching vibrations of the aldehyde structure present in lemongrass oil. Furthermore, the FTIR spectra of chitosan/ascorbic acid film and lemongrass/chitosan/ascorbic acid film were similar, revealing that there is no chemical reaction produced new compounds [11].

Mechanical properties are one of the important characteristics of food packaging materials. Packaging materials must be able to resist mechanical stress to protect food packaged from damage and to maintain its quality during the logistics process [13]. The effect of lemongrass oil in chitosan/ascorbic acid film on mechanical properties such as tensile strength (TS) and elongation (E) was shown in Figure 5.

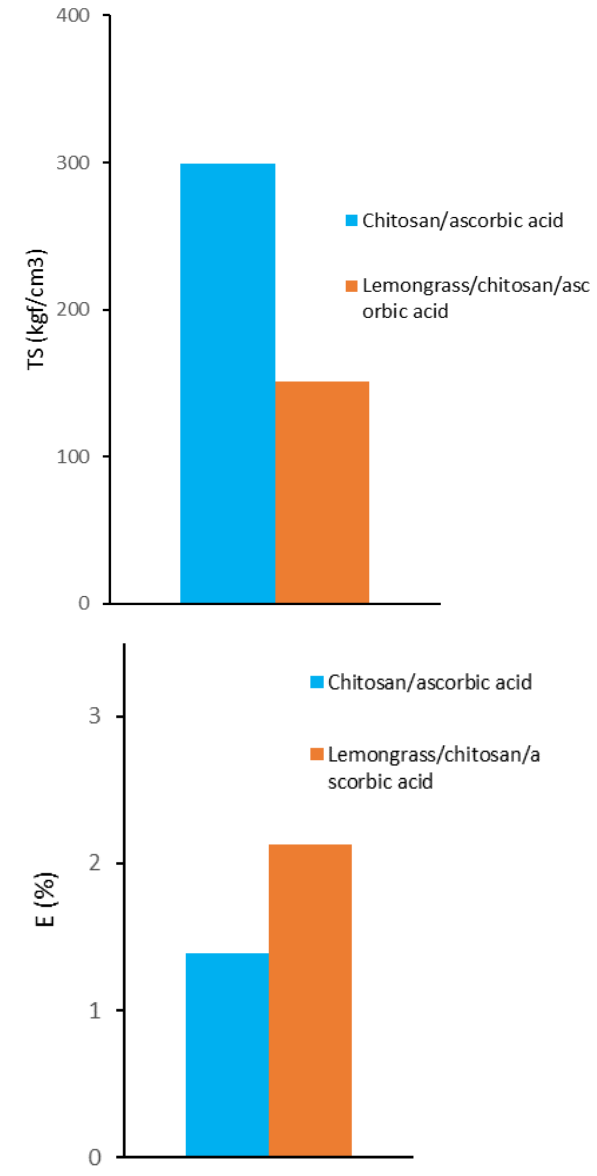

Figure 5. Tensile strength (a) and elongation (b) of the films.
The chitosan/ascorbic film has TS value of 299 $\mathrm{kgf} / \mathrm{cm}^{2}$ which then decreased to $151 \mathrm{kgf} / \mathrm{cm}^{2}$ when incorporated with lemongrass oil. The addition of lemongrass oil disrupted the chitosan network and produced the cross-linker effect which decreased the TS of chitosan/ascorbic film [10]. For application as packaging, the mechanical properties of the film must be improved, the tensile strength must be increased but not lose its elasticity, otherwise the film has no potential to be used as a packaging material. [9]. The percentage E of chitosan/ascorbic acid was increased with the addition of the lemongrass oil from $1,39 \%$ to $2,13 \%$ as seen as in Figure 3 (b)

\section{CONCLUSION}

Incorporating lemongrass oil in chitosan/ascorbic acid film decreased moisture content and water solubility but increased the opacity. The value of WVTR in chitosan/ascorbic acid film was decreased with the addition of lemongrass oil. The addition of lemongrass oil also has effect in mechanical properties, decreased the tensile strength and increase the elongation. For further application, it can be used as an antimicrobial film for active packaging

\section{ACKNOWLEDGMENT}

This research was funded by PDD (Penelitian Disertasi Doktor) from Kemenristekdikti Republik Indonesia No.NBK-403/UN2.RST/HKP.05.00/2020. We acknowledge Center for Chemical and Packaging for the equipment to this research.

\section{REFERENCES}

[1] Broek L A M Van Den, Knoop R J I, Kappen F H J and Boeriu C G 2015 Chitosan films and blends for packaging material Carbohydr. Polym. 116 237-42

[2] Cazón P and Vázquez M 2020 Mechanical and barrier properties of chitosan combined with other components as food packaging film Environ. Chem. Lett. 18 257-67

[3] Rahman L and Goswami J 2021 Recent development on physical and biological properties of chitosanbased composite films with natural extracts: A review J. Bioact. Compat. Polym.

[4] Abdollahi M, Rezaei M and Farzi G 2012 Improvement of active chitosan film properties with rosemary essential oil for food packaging Int. J. Food Sci. Technol. 47 847-53

[5] Yunilawati R, Handayani W, C A A, Amalia B and Imawan C 2020 Antimicrobial Label from Lemongrass Oil Incorporated with Chitosan / 
Ascorbic Acid 2nd International Conference of Essential Oil Indonesia (ICEO) pp 147-52

[6] ASTM 2016 E96-E96M-16 - Standard Test Method for Water Vapor Transmission of Material

[7] ASTM 2018 D882-18 - Standard Test Method for Tensile Properties of Thin Plastic SheetingTensile Properties of Plastic Film

[8] Peng Y and Li Y 2014 Combined effects of two kinds of essential oils on physical, mechanical and structural properties of chitosan fi lms Food Hydrocoll. 36 287-93

[9] David C, Serio G A and Grande-tovar C D 2018 Chitosan films incorporated with Thymus capitatus essential oil: mechanical properties and antimicrobial activity against degradative bacterial species isolated from tuna ( Thunnus sp .) and swordfish ( Xiphias gladius ) Food Sci Technol 55 4256-65

[10] Han Lyn F and Nur Hanani Z A 2020 Effect of Lemongrass (Cymbopogon citratus) Essential Oil on the Properties of Chitosan Films for Active Packaging J. Packag. Technol. Res. 4 33-44

[11] Liu T, Wang J, Chi F, Tan Z and Liu L 2020 Development and Characterization of Novel Active Chitosan Films Containing Fennel and Peppermint Essential Oils Coatings 10936

[12] Noshirvani N, Ghanbarzadeh B and Gardrat C 2017 Cinnamon and ginger essential oils to improve antifungal, physical and mechanical properties of chitosan-carboxymethyl cellulose fi lms Food Hydrocoll. 70 36-45

[13] Priyadarshi R, Kumar B, Deeba F and Kulshreshtha A 2018 Chitosan fi lms incorporated with Apricot ( Prunus armeniaca ) kernel essential oil as active food packaging material Food Hydrocoll. 85 15866 